\title{
The Effect of Experiential Marketing on Customer Satisfaction of Cafe Tik Tok in Bengkulu City
}

\section{Pengaruh Experiential Marketing terhadap Kepuasan Pelanggan Cafe Tik Tok di Kota Bengkulu \\ Yudi Ariantara') \\ 1) Department of Informatic, Faculty of Computer Science, Universitas Dehasen Bengkulu Email: 1) angel_arie23@yahoo.co.id}

\begin{abstract}
How to Cite:
Ariantara, Y. (2021). The Effect of Experiential Marketing on Customer Satisfaction of Cafe Tik Tok in Bengkulu City. EMAK: Jurnal Ekonomi Manajemen Akuntansi Dan Keuangan, 2(3). DOI: https://doi.org/10.53697/emak.v2i3
\end{abstract}

ARTICLE HISTORY

Received [1 Juni 2021]

Revised [10 Juni 2021]

Accepted [3 juli 2021]

\section{KEYWORDS}

Experiential Marketing, Satisfaction of Cafe Tik Tok

This is an open access article under the $C C-B Y$-SA license

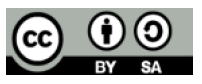

\section{ABSTRAK}

Tujuan penelitian ini adalah untuk mengetahui Pengaruh Experiential Marketing terhadap Kepuasan Pelanggan Cafe Tik Tok di Kota Bengkulu. Jenis penelitian ini adalah penelitian deskriptif kuantitatif untuk memperoleh gambaran mengenai pengaruh strategi experiential marketing terhadap kepuasan Pelanggan di Cafe Tik Tok. Uji t menunjukkan ada atau tidaknya pengaruh satu variabel penjelas atau independen secara individual dalam menerangkan variasi variabel dependen dan digunakan untuk mengetahui ada atau tidaknya pengaruh masing-masing variabel independen secara individual terhadap variabel dependen yang diuji pada tingkat signifikansi 0,05 (Ghozali, 2009). Dalam penelitian ini, hipotesis pertama adalah apakah terdapat pengaruh antara Sense (X1) terhadap variabel Kepuasan Pelanggan (Y). Untuk mengetahui apakah hipotesis ini dapat diterima atau ditolak maka dilakukan pengujian dengan menggunakan program SPSS versi 23. Hasil pengujian variabel jaminan (Act) menunjukkan nilai t hitung $=2,513$ dengan nilai signifikansi sebesar 0,013 $<0,05$. Dengan nilai signifikansi di bawah 0,05 tersebut menunjukkan bahwa jaminan (Act) memiliki pengaruh yang signifikan terhadap kepuasan Pelanggan. Hal ini berarti Hipotesis 4 diterima. Hasil pengujian variabel kepedulian (Relate) menunjukkan nilai t hitung $=2,205$ dengan nilai signifikansi sebesar 0,029<0,05. Dengan nilai signifikansi di bawah 0,05 tersebut menunjukkan bahwa kepedulian (Relate) memiliki pengaruh yang signifikan terhadap kepuasan Pelanggan. Hal ini berarti Hipotesis 5 diterima.

\section{ABSTRACT}

The purpose of this study was to determine the effect of experiential marketing on customer satisfaction at Cafe Tik Tok in Bengkulu City. This type of research is descriptive quantitative research to obtain an overview of the effect of experiential marketing strategy on customer satisfaction at Cafe Tik Tok. The t test shows the presence or absence of the influence of one explanatory or independent variable individually in explaining the variation of the dependent variable and is used to determine the presence or absence of the influence of each independent variable individually on the dependent variable tested at a significance level of 0.05 (Ghozali, 
2009). In this study, the first hypothesis is whether there is an influence between Sense (X1) on the Customer Satisfaction variable (Y). To find out whether this hypothesis can be accepted or rejected, a test is carried out using the SPSS version 23 program. The test results for the guarantee variable (Act) show the $t$-count $=2.513$ with a significance value of 0.013 $<0.05$. With a significance value below 0.05 , it indicates that the guarantee (Act) has a significant effect on customer satisfaction. This means that Hypothesis 4 is accepted. The results of the test of the concern variable (Relate) show the value of $t$ count $=2.205$ with a significance value of $0.029<0.05$. With a significance value below 0.05 , it shows that concern (Relate) has a significant influence on customer satisfaction. This means that Hypothesis 5 is accepted.

\section{PENDAHULUAN}

Saat ini, persaingan di dunia bisnis semakin ketat dan dapat menjadi suatu ancaman bagi pelaku usaha. Untuk dapat menghadapi persaingan tersebut, para pelaku usaha harus bisa melakukan Inovasi-inovasi yang baru juga diharapkan dapat memanjakan para masyarakat yang bertindak sebagai konsumen. Perusahaan dapat mempengaruhi konsumen dengan menciptakan suatu produk atau jasa yang bisa menarik hati para konsumen, dengan harapan konsumen akan datang berkunjung kembali untuk menikmati produk atau jasa yang ditawarkan tersebut.

Termasuk dengan bisnis cafe, saat ini begitu banyak diminati oleh masyarakat. Bisnis cafe juga tampaknya tidak terpengaruh oleh terpaan krisis global dikarenakan dalam kondisi apapun, manusia sangat membutuhkan pangan. Manusia pasti membutuhkan makanan untuk pemenuhan kebutuhan jasmani (Sigma, 2012). Setelah kebutuhan dasar terpenuhi, manusia baru akan bisa memikirkan untuk mencapai kebutuhan lainnya.

Experiential marketing adalah suatu konsep pemasaran bertujuan untuk membentuk Pelanggan-Pelanggan yang loyal dengan menyentuh emosi mereka dan memberikan suatu feeling yang positif terhadap produk dan Jasa (Kartajaya, 2006). Konsep ini bertujuan agar para konsumen dapat mendapatkan pelayanan maksimal dari para penjual produk dan jasa. Tujuan utama dari experiential marketing adalah para pelaku usaha dapat melayani konsumen dengan baik melalui 5 aspek yaitu panca indera (sense), perasaan (feel), cara berpikir (think), kebiasaan (act) dan relasi (relate). Diharapkan semua produk atau jasa yang ditawarkan memiliki 5 asepek tersebut. Konsumen harus bisa merasakan, memikirkan dan bertindak sesuai harapan, sehingga di hati Pelanggan tercipta rasa memiliki terhadap suatu produk atau jasa sehingga akhirnya hal ini menjadi diferensiasi bagi produk atau jasa tersebut (Kartajaya, 2006).

Schmitt (1999) menyatakan bahwa strategi experiential marketing mempunyai manfaat untuk membangkitkan kembali merek yang sedang merosot, membedakan satu produk dengan produk pesaing, menciptakan citra dan identitas sebuah perusahaan, mempromosikan inovasi, membujuk percobaan pembelian dan kepuasaan

penelitian ini mengangkat isu experiential marketing dengan studi kasus di salah satu cafe yang ada di Kota Bengkulu dengan objek penelitian yang diambil adalah para Pelanggan cafe tersebut karena cafe seharusnya menawarkan produk makanan dan minuman dengan pelayanan yang terbaik baik dari segi citarasa masakan, keramahan, interior cafe yang menarik dan sebagainya.

Kepuasan konsumen dilihat dari sejauh mana manfaat sebuah produk dirasakan (perceived) sesuai dengan apa yang diharapkan Pelanggan (Amir, 2005). Kepuasan Pelanggan merupakan hal yang sangat penting bagi perusahaan, karena jika pelanggan puas, maka pelanggan akan menjadi loyal, datang kembali untuk membeli, serta menyebarkan informasi positif kepada rekan, teman dan keluarga pelanggan tersebut. 
Beberapa peneliti seperti Liljander dan Strandvik (1997); Nunes dan Cespedes (2003) menyebutkan bahwa sisi emosional konsumen berpengaruh terhadap kepuasan konsumen. Nunes dan Cespedes (2003) lebih lanjut menyebutkan, saat perusahaan memfokuskan diri pada bentuk fisik suatu produk semata dan benar-benar melupakan aspek emosional dan nilai-nilai lain, perusahaan akan kehilangan konsumennya pada jangka panjang. Strategi bisnis yang berkembang saat ini adalah strategi yang mengaitkan aspek emosional konsumen dengan merek, komunitas, dan merek perusahaan melalui pengalaman-pengalaman yang dirasakan oleh konsumen (Mascarenhas, et al., 2006). Dengan demikian dapat dikatakan bahwa experiential marketing sangat penting baik bagi konsumen maupun pelaku usaha.

Faktor penting lain konsumen berkunjung ke Cafe bukan hanya untuk menikmati hidangan makan dan minuman saja, tetapi juga untuk berekreasi bersama keluarga dan teman teman, walaupun sekedar untuk pengganti suasana baru diluar rutinitas keseharian para konsumen yang disibukkan dengan rutinitas sehari-hari. Salah satu cafe yang terkenal di Bengkulu ialah Cafe Tik Tok. Cafe Tik Tok tidak hanya menawarkan kualitas yang baik dari setiap produknya melainkan juga menawarkan konsep yang berbeda dari interiornya yang sangat memanjakan mata sehingga bisa digunakan pelanggan untuk berfoto di spot yang ada di Cafe Tik tok. Cafe Tik Tok juga sangat menjaga kepuasan para Pelanggannya. Oleh karenanya tidak heran kalau Cafe Tik Tok menjadi salah satu cafe yang menjadi idola bagi masyarakat di Kota Bengkulu.

Tik Tok menjadi trend-setter untuk para kalangan muda di kota Bengkulu dengan pendekatan baru yaitu experiential marketing, hal tersebut membuat banyak Cafe cafe lain yang mengikuti baik dari segi produk makanan dan minuman yang ditawarkan sampai dengan konsep interiornya pun banyak yang memiliki persamaan dengan Cafe Tik Tok. Untuk itu Tik Tok selalu menunjukkan keunggulan kompetitif agar dapat mempertahankan kelangsungan hidup perusahaan dengan cara menyediakan produk produk yang inovatif dan sesuai dengan harapan konsumen yang nantinya diharapkan dapat memberikan kepuasan kepada para pelanggan.

Kotler (2000) mengatakan bahwa kepuasan konsumen merupakan tingkat perasaan seseorang setelah membandingkan antara kinerja produk yang ia rasakan dengan harapannya. (Tjiptono, 2000) menyatakan kesuksesan dalam persaingan akan dapat dipenuhi apabila perusahaan mampu menciptakan kepuasan dan mempertahankan Pelanggan.

Mempertahankan Pelanggan jauh lebih murah dibandingkan merebut Pelanggan baru (Marknesis, 2009). Salah satu pendekatan dalam menciptakan kepuasan dan kepuasaan Pelanggan adalah dengan penerapan experiential marketing (Setiawan, 2009). Experiential marketing dapat dilakukan salah satunya melalui Strategic Experiential Modules (SEM's) yaitu sense, feel, think, act dan relate. Oleh karena itu Perusahaan harus mampu bertahan dalam jangka penjang dengan cara harus membuat Pelanggan selalu puas dan menjadi loyal.

\section{LANDASAN TEORI}

\section{Kepuasan Konsumen, Experiential Marketing}

Mowen dan Minor (2002) kepuasan konsumen didefinisikan sebagai keseluruhan sikap yang ditujukan konsumen atas barang atau jasa setelah mereka memperoleh dan menggunakannya. Kepuasan atau ketidakpuasan konsumen adalah respon terhadap evaluasi ketidaksesuaian atau diskonfirmasi yang dirasakan antara harapan sebelumnya dan kinerja aktual produk yang dirasakan setelah pemakaian (Nasution, 2004). (Tjiptono, 2005) mengemukakan bahwa kepuasan konsumen merupakan respon emosional terhadap pengalaman yang berkaitan dengan produk atau jasa yang dibeli.

Lenderman (2006) mengatakan bahwa experiential marketing adalah metodologi pemasaran yang dapat menjembatani antara permintaan konsumen yang meningkat dengan ajakan pemasar dan mereknya sesuai dengan produknya, dan untuk mengatasi lambatnya langkah pemasar tradisional untuk segera meninggalkan pemasaran melalui media massa yang dengan 
hanya satu arah, memerintah dan mengendalikan jalan untuk membangun merek yang telah biasa mereka lakukan selama beberapa dekade. Feel marketing ditujukan terhadap perasaan dan emosi konsumen dengan tujuan mempengaruhi pengalaman yang dimulai dari suasana hati yang lembut sampai dengan emosi yang kuat terhadap kesenangan dan kebanggaan (Schmiit, 1999). Feel adalah suatu perhatian-perhatian kecil yang ditunjukan pada konsumen dengan tujuan untuk menyentuh emosi Pelanggan dengan luar biasa, menurut (Kartajaya, 2012). Hal ini berhubungan dengan bagaimana menciptakan perasaan enak atau nyaman (feel good) bagi para konsumen, mood dan emosi dilibatkan secara intens karena hal tersebut berkaitan dengan suasana hati dan emosi jiwa yang mampu membangkitkan kebahagiaan atau bahkan kesedihan.

Tipe experience yang bertujuan untuk mempengaruhi perilaku, gaya hidup dan interaksi dengan konsumen (Schmitt, 1999). Act marketing adalah suatu cara membentuk persepsi Pelanggan terhadap produk dan jasa yang bersangkutan (Kartajaya, 2006). Act marketing didesain untuk menciptakan pengalaman konsumen dalam hubungannya dengan physical body, lifestyle dan interaksi dengan orang lain. Act marketing berhubungan dengan bagaimana membuat orang berbuat sesuatu dan mengekspresikan gaya hidupnya. Pesan-pesan yang memotivasi, menginspirasi dan bersifat spontan dapat menyebabkan Pelanggan untuk berbuat hal-hal dengan cara yang berbeda, mencoba dengan cara yang baru merubah hidup mereka lebih baik. Relate marketing berisikan aspek-aspek dari sense, feel, think, act marketing serta menitik beratkan pada penciptaan persepsi positif dimata Pelanggan (Schmitt, 1999). Tujuan dari pemasaran relate adalah menghubungkan diri pribadi seseorang kepada konteks sosial budaya didalam suatu merek kemudian akan menciptakan suatu identitas sosial kepada dirinya sendiri. Relate menjelaskan suatu hubungan dengan orang lain. Kelompok sosial lainnya (pekerjaan, etnik atau gaya hidup) perhimpunan masyarakat atau kebudayaan (Schmitt, 1999).

\section{METODE PENELITIAN}

Jenis penelitian ini adalah penelitian deskriptif kuantitatif untuk memperoleh gambaran mengenai pengaruh strategi experiential marketing terhadap kepuasan Pelanggan di Cafe Tik Tok. Sugiyono (2011) memberi pengertian mengenai penelitian deskriptif kuantitatif sebagai suatu metode dalam meneliti status kelompok manusia, suatu objek, suatu set kondisi, suatu sistem pemikiran atau kelas peristiwa pada masa sekarang. Tujuan penelitian deskriptif ini adalah untuk membuat deskripsi, gambaran atau lukisan secara sistematis, faktual dan akurat mengenai faktafakta, sifat-sifat serta hubungan antar fenomena yang diselidiki melalui perhitungan angka-angka statistik dan pengujian hipotesis.

Populasi adalah keseluruhan subjek penelitian (Arikunto, 2010). Sementara Bungin (2006) menyebutkan, populasi adalah serumpun atau sekelompok objek yang menjadi sasaran penelitian. Berdasarkan definisi populasi maka populasi dalam penelitian ini adalah semua Pelanggan Cafe Tik Tok Kota Bengkulu. Penelitian ini menggunakan rancangan sampel nonprobabilitas (nonprobability sampling design) dengan teknik acidental sampling dalam memperoleh informasi dari responden.

Acidental sampling ini memperoleh sampel disaat menemukan subjek secara kebetulan dan lebih memudahkan penelitian. Kriteria sampel yang dijadikan responden dalam penelitian ini adalah mulai dari remaja, dewasa, pelajar, mahasiswa, sudah bekerja, perempuan, laki-laki pelaanggan

Cafe Tik Tok Kota Bengkulu. Mengenai ukuran sampel minimal, menurut Hair et al. (2010) jumlah sampel minimal yang dibutuhkan berkisar antara 100-300 observasi.

\section{HASIL DAN PEMBAHASAN}

\section{Hasil dan Pembahasan}

Metode yang digunakan untuk menganalisis pengaruh dari berbagai variabel independen terhadap satu variabel dependen. Analisis regresi berganda digunakan untuk mengetahui seberapa 
besar pengaruh variabel bebas (Independent) yaitu: Sense (X1), Feel (X2), Think (X3), Act (X4) dan Relate (X5) terhadap variabel terikat (dependen) Kepuasan Pelanggan (Y).

Tabel 1. Analisis Regresi Linier Berganda

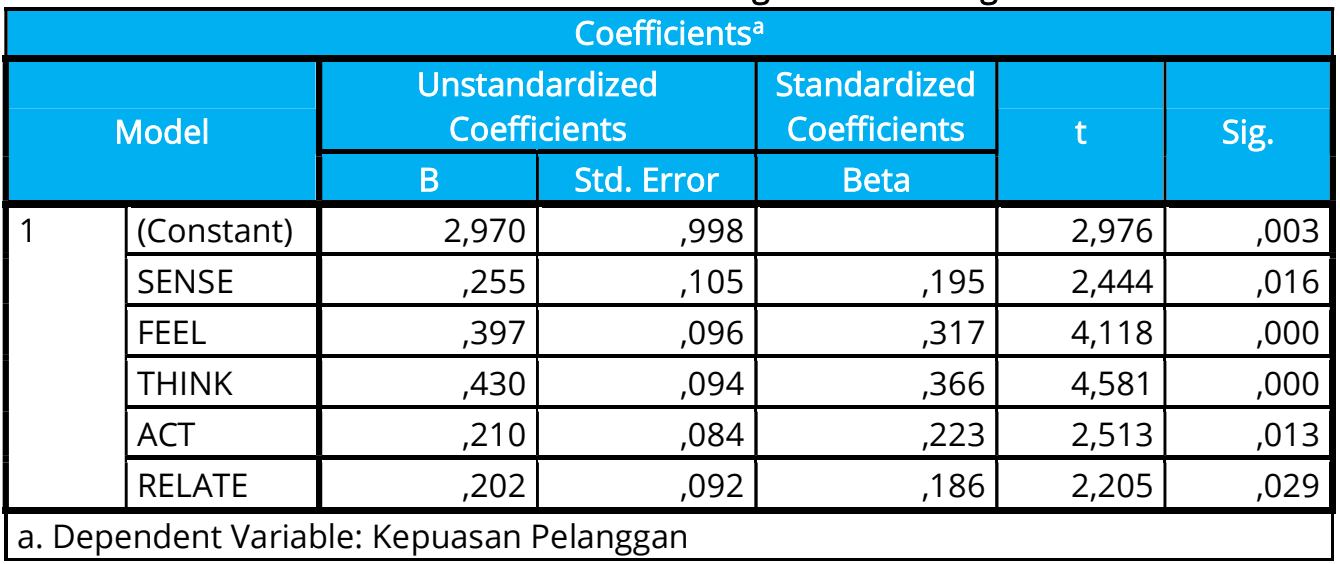

Sumber: Hasil Penelitian 2021, diolah

Berdasarkan output SPSS pada Tabel 4.5 diperoleh persamaan regresi pengaruh antara Sense (X1), Feel (X2), Think (X3), Act (X4) dan Relate (X5) terhadap variabel Kepuasan Pelanggan (Y):

$Y=a+\beta 1 \times 1+\beta 2 \times 2+\beta 2 \times 3+\beta 2 \times 4+\beta 2 \times 5+e$

$Y=0,195 \times 1+0,317 \times 2+0,366 \times 3+0,223 \times 4+0,186 \times 5+e$

Persamaan regresi di atas dapat dijelaskan sebagai berikut:

- Koefisien regresi variabel Sense $\left(X_{1}\right)$ sebesar 0, 195 artinya jika variabel independen lain nilainya tetap dan Sense $\left(X_{1}\right)$ mengalami kenaikan, maka Kepuasan Pelanggan $(Y)$ akan mengalami kenaikan. Sebaliknya penurunan pada variabel Sense akan menurunkan Kepuasan Pelanggan.

- $\quad$ Nilai Koefisien beta pada variabel Feel $\left(X_{2}\right)$ sebesar 0, 317 yang berarti setiap perubahan pada variabel Feel (X2) akan mengakibatkan perubahan Kepuasan Pelanggan (Y). Feel (X2) Mengalami kenaikan, maka Kepuasan Pelanggan (Y) akan mengalami kenaikan. Sebaliknya penurunan pada variabel Feel akan menurunkan Kepuasan Pelanggan.

- $\quad$ Nilai Koefisien beta pada variabel Think $\left(\mathrm{X}_{2}\right)$ sebesar 0,366 yang berarti setiap perubahan pada variabel Think (X2) akan mengakibatkan perubahan Kepuasan Pelanggan (Y). Think (X2) Mengalami kenaikan, maka Kepuasan Pelanggan (Y) akan mengalami kenaikan. Sebaliknya penurunan pada variabel Think akan menurunkan Kepuasan Pelanggan.

- $\quad$ Nilai Koefisien beta pada variabel $A c t\left(\mathrm{X}_{2}\right)$ sebesar 0,223 yang berarti setiap perubahan pada variabel Act (X2) akan mengakibatkan perubahan Kepuasaan Pelanggan (Y). Act (X2) Mengalami kenaikan, maka Kepuasan Pelanggan (Y) akan mengalami kenaikan. Sebaliknya penurunan pada variabel Act akan menurunkan Kepuasan Pelanggan.

- $\quad$ Nilai Koefisien beta pada variabel Relate $\left(\mathrm{X}_{2}\right)$ sebesar 0,186 yang berarti setiap perubahan pada variabel Relate (X2) akan mengakibatkan perubahan Kepuasan Pelanggan (Y). Relate (X2) Mengalami kenaikan, maka Kepuasan Pelanggan (Y) akan mengalami kenaikan.Sebaliknya penurunan pada variabel Relate akan menurunkan Kepuasan Pelanggan.

Uji Hipotesis 1 
Uji t menunjukkan ada atau tidaknya pengaruh satu variabel penjelas atau independen secara individual dalam menerangkan variasi variabel dependen dan digunakan untuk mengetahui ada atau tidaknya pengaruh masing-masing variabel independen secara individual terhadap variabel dependen yang diuji pada tingkat signifikansi 0,05 (Ghozali, 2009). Dalam penelitian ini, hipotesis pertama adalah apakah terdapat pengaruh antara Sense (X1) terhadap variabel Kepuasan Pelanggan (Y). Untuk mengetahui apakah hipotesis ini dapat diterima atau ditolak maka dilakukan pengujian dengan menggunakan program SPSS versi 23.

Berdasarkan Tabel 4.5 diperoleh Hasil pengujian variabel bukti nyata (Sense) menunjukkan nilai t hitung $=2,444$ dengan nilai signifikansi sebesar $0,016<0,05$. Dengan nilai signifikansi di bawah 0,05 tersebut menunjukkan bahwa bukti nyata (Sense) memiliki pengaruh yang signifikan terhadap kepuasan Pelanggan. Hal ini berarti Hipotesis 1 diterima.

\section{Uji Hipotesis 2}

Menurut Ghozali (Suharso, 2006) untuk menilai ketepatan (goodness of fit) suatu model regresi yang diduga, adalah diukur dari nilai statistik t. Suatu perhitungan statistik disebut signifikan secara statistik apabila nilai uji statistiknya berada dalam daerah kritis (daerah dimana hipotesa H0 ditolak). Sebaliknya disebut tidak signifikan apabila nilai uji statistiknya berada dalam daerah dimana hipotesa HO diterima. Uji t untuk menguji kemaknaan atau keberartian koefisien regresi partial. probabilitas kesalahan lebih kecil dari 5\% $(p<0.05)$. Dalam penelitian ini, hipotesis kedua adalah apakah terdapat pengaruh Feel $\left(\mathrm{X}_{2}\right)$ terhadap Kepuasan Pelanggan $(\mathrm{Y})$. Untuk mengetahui apakah hipotesis ini dapat diterima atau ditolak maka dilakukan pengujian dengan menggunakan program SPSS versi 23.

Berdasarkan Tabel 4.5 diketahui bahwa Hasil pengujian variabel kehandalan (Feel) menunjukkan nilai t hitung $=4,118$ dengan nilai signifikansi sebesar $0,00<0,05$. Dengan nilai signifikansi di bawah 0,05 tersebut menunjukkan bahwa kehandalan (Feel) memiliki pengaruh yang signifikan terhadap kepuasan Pelanggan. Hal ini berarti Hipotesis 2 diterima.

\section{Uji Hipotesis 3}

Uji t menunjukkan ada atau tidaknya pengaruh satu variabel penjelas atau independen secara individual dalam menerangkan variasi variabel dependen dan digunakan untuk mengetahui ada atau tidaknya pengaruh masing-masing variabel independen secara individual terhadap variabel dependen yang diuji pada tingkat signifikansi 0,05 (Ghozali, 2009). Dalam penelitian ini, hipotesis pertama adalah apakah terdapat pengaruh antara Sense (X1) terhadap variabel Kepuasan Pelanggan (Y). Untuk mengetahui apakah hipotesis ini dapat diterima atau ditolak maka dilakukan pengujian dengan menggunakan program SPSS versi 23.

Hasil pengujian variabel daya tanggap (Think) menunjukkan nilai t hitung $=4,581$ dengan nilai signifikansi sebesar $0,00<0,05$. Dengan nilai signifikansi di bawah 0,05 tersebut menunjukkan bahwa daya tanggap (Think) memiliki pengaruh yang signifikan terhadap kepuasan Pelanggan. Hal ini berarti Hipotesis 3 diterima.

\section{Uji Hipotesis}

Uji t menunjukkan ada atau tidaknya pengaruh satu variabel penjelas atau independen secara individual dalam menerangkan variasi variabel dependen dan digunakan untuk mengetahui ada atau tidaknya pengaruh masing-masing variabel independen secara individual terhadap variabel dependen yang diuji pada tingkat signifikansi 0,05 (Ghozali, 2009). Dalam penelitian ini, hipotesis pertama adalah apakah terdapat pengaruh antara Sense (X1) terhadap variabel Kepuasan Pelanggan (Y). Untuk mengetahui apakah hipotesis ini dapat diterima atau ditolak maka dilakukan pengujian dengan menggunakan program SPSS versi 23. 
Hasil pengujian variabel jaminan (Act) menunjukkan nilai t hitung $=2,513$ dengan nilai signifikansi sebesar 0,013<0,05. Dengan nilai signifikansi di bawah 0,05 tersebut menunjukkan bahwa jaminan (Act) memiliki pengaruh yang signifikan terhadap kepuasan Pelanggan. Hal ini berarti Hipotesis 4 diterima.

\section{Uji Hipotesis}

Uji t menunjukkan ada atau tidaknya pengaruh satu variabel penjelas atau independen secara individual dalam menerangkan variasi variabel dependen dan digunakan untuk mengetahui ada atau tidaknya pengaruh masing-masing variabel independen secara individual terhadap variabel dependen yang diuji pada tingkat signifikansi 0,05 (Ghozali, 2009). Dalam penelitian ini, hipotesis pertama adalah apakah terdapat pengaruh antara Sense (X1) terhadap variabel Kepuasan Pelanggan (Y). Untuk mengetahui apakah hipotesis ini dapat diterima atau ditolak maka dilakukan pengujian dengan menggunakan program SPSS versi 23.

Hasil pengujian variabel kepedulian (Relate) menunjukkan nilai t hitung $=2,205$ dengan nilai signifikansi sebesar 0,029 $<0,05$. Dengan nilai signifikansi di bawah 0,05 tersebut menunjukkan bahwa kepedulian (Relate) memiliki pengaruh yang signifikan terhadap kepuasan Pelanggan. Hal ini berarti Hipotesis 5 diterima.

\section{Uji Determinasi (Adjusted R2)}

Koefisien determinasi (Adjusted R2) bertujuan untuk mengetahui seberapa besar kemampuan variabel independen (Experiential Marketing) menjelaskan variabel dependen (Kepuasan Pelanggan). Dalam output SPSS, koefisien determinasi terletak pada tabel Model Summary dan tertulis Adjusted R Square. Nilai R2 sebesar 1, berarti pengaruh variabel dependen (Kepuasan Pelanggan). seluruhnya dapat dijelaskan variabel independen independen (Experiential Marketing). Jika nilai Adjusted R2 berkisar antara 0 sampai dengan 1, berarti semakin kuat kemampuan variabel independen dapat menjelaskan pengaruh variabel dependen (Ghozali, 2009).

Tabel 2. Hasil Uji Diterminan

\begin{tabular}{|l|r|r|r|r|}
\hline \multicolumn{5}{|c|}{ Model Summary } \\
\hline Model & \multicolumn{1}{|c|}{$\mathrm{R}$} & R Square & $\begin{array}{c}\text { Adjusted R } \\
\text { Square }\end{array}$ & $\begin{array}{c}\text { Std. Error of } \\
\text { the Estimate }\end{array}$ \\
\hline 1 &, $741^{\mathrm{a}}$ &, 549 &, 533 & 1,109 \\
\hline \multicolumn{4}{|l|}{ a. Predictors: (Constant), RELATE, SENSE, THINK, FEEL, ACT } \\
\hline
\end{tabular}

Berdasarkan perhitungan pada Tabel 4.9 dapat diketahui kedua variabel independen (Experiential Marketing) menunjukan Adjusted $\mathrm{R}^{2}$ sebesar 0,533 atau 53, 3\%. Hal ini berarti variabel Kepuasan Pelanggan dapat dijelaskan oleh variabel (Experiential Marketing) sebesar 53,3\%. Sisanya $46.7 \%$ dijelaskan oleh variabel diluar model.

\section{KESIMPULAN DAN SARAN}

\section{Kesimpulan}

1. Sense berpengaruh signifkan terhadap Kepuasan Pelanggan Cafe Tik Tok Bengkulu. Artinya semakin bagus Sense yang dilihat dan dirasakan Pelanggan yang menggunakan Cafe Tik Tok maka akan semakin bagus dan meningkat juga Kepuasan Pelanggan terhadap Cafe Tik Tok di kota Bengkulu.

2. Feel berpengaruh signifkan terhadap Kepuasan Pelanggan Cafe Tik Tok di kota Bengekulu. Artinya semakin baik Feel yang ditawarkan pihak perusahaan kepada Pelanggan, maka akan 
semakin bagus dan meningkat juga Kepuasan Pelanggan Cafe Tik Tok yang ada di kota Bengekulu.

3. Think berpengaruh signifkan terhadap Kepuasan Pelanggan Cafe Tik Tok Bengkulu. Artinya semakin bagus Think yang dirasakan Pelanggan yang menggunakan Cafe Tik Tok maka akan semakin bagus dan meningkat juga Kepuasan Pelanggan terhadap Cafe Tik Tok di kota Bengkulu.

4. Act Nyata berpengaruh signifkan terhadap Kepuasan Pelanggan Cafe Tik Tok Bengekulu. Artinya semakin bagus Act yang dirasakan Pelanggan yang menggunakan Cafe Tik Tok maka akan semakin bagus dan meningkat juga Kepuasan Pelanggan terhadap Cafe Tik Tok di kota Bengkulu.

5. Relate berpengaruh signifkan terhadap Kepuasan Pelanggan Cafe Tik Tok Bengekulu. Artinya semakin bagus Relate yang dirasakan Pelanggan yang menggunakan produk Cafe Tik Tok maka akan semakin bagus dan meningkat juga Kepuasan Pelanggan terhadap Cafe Tik Tok di kota Bengkulu.

Saran

1. Hasil penelitian menunjukan Experiential Marketing adalah keyakinan Pelanggan terhadap produk, dimana perusahaan harus menciptakan Experiential Marketing yang baik pada produk-produk mereka dan menjadi factor-faktor yang mempengaruhi tingkat kepuasaan Pelanggan, Berdasarkan hasil pengujian menunjukkan bahwa Experiential Marketing berperan penting dalam usaha meningkatkan kepuasaan Pelanggan. Untuk itu sebaiknya pihak Cafe Tik Tok menerapkan strategi marketing yang tepat untuk memberikan keyakinan terhadap Cafe Tik Tok kepada Pelanggan sehingga Pelanggan akan merasa semakin yakin dan puas dengan Cafe Tik Tok .

2. Diharapkan pihak Cafe Tik Tok dapat mempertahankan dan meningkatkan Experiential Marketing yang sudah dimilikinya saat ini. Dengan Experiential Marketing yang baik maka tamu Pelanggan akan puas pada saat menggunakan Cafe Tik Tok, sehingga dapat meningkatkan citra positif di mata tamu Pelanggan dan pada akhirnya akan tercipta kepuasan Pelanggan yang bagus pada Cafe Tik Tok .

\section{DAFTAR PUSTAKA}

Adisasmita, Rahardja. 2010. Pembangunan Kawasan dan Tata Ruang. Yogyakarta : Graha Ilmu.

Alkilani. K. et al, "The Impact of Experiential Marketing and Customer Satisfaction on Customer Commitment in the World of Social Networks",Asian Social Science Vol. 9 No. 1, 2013.

Amir, M. Taufiq. 2005. Dinamika Pemasaran: Jelajahi \& Rasakan. Jakarta: PT.Raja Grafindo Persada.

Andreani, Fransisca. 2007.Experiential Marketing (Sebuah Pendekatan Pemasaran). Jurnal Manajemen Pemasaran, Vol.2 No.1 April hal.1 - 8.

Arbuckle, James L, 1997, Amos 7.0 User's Guide. Chicago, IL: SPSS Inc.

Arbuckle, J.L. and Wothke, W.(1999). AMOS users guide version 4.0. Chicago, IL: Small Water.

Bassi, Ana. 2010. 1001 Teh - dari Asal Usul, Khasiat hingga Racikan Teh. Yogyakarta: CV Andi, BeStBook.

Baumgartner, H \& Homburg, C. 1996. Applications of structural equation modeling in marketing and consumer research: A review. International Journal of Research in Marketing. (13).139-161.

Donnelly. (2009). Building Customer Loyalty. A Customer Experience Based Approach in a Tourism Context. Irlandia: Waterford institute of technology.June 2009.

Edwin Japarianto, 2007, Analisa Experiential Marketing sebagai Pengukur Kepuasaan Pelanggan Hotel Majapahit Surabaya dengan Pemasaran Relasional sebagai Variabel Intervening, 34-42.

Eka Wulansari, 2007, Analisis Kepuasan Pelanggan terhadap Kualitas pelayanan Perusahaan Daerah Air Minum (Penelitian Kuantitatif Deskriptif pada Pelanggan Perusahaan Daerah Air Minum 
Cabang Semarang Selatan), Skripsi tidak dipublikasikan, Semarang : Universitas Negeri Semarang.

Elvina. 2011. Hubungan Gangguan Fungsi Kognitif dengan Hipertensi ditinjau dari Aspek IL-6 dan TLF-ALFA. Tesis. Padang: Pasca Sarjana UNPA.

Engel, Blackwell, dan Miniard. (1994).Perilaku Konsumen, Binarupa Aksara, Jakarta

Engel, J. F., Blackwell, R. D. \& Miniard, P. W. (2008). Customer Behavior, 8th Edition. The Dryden Press, Harcount Brace College Publishers.

Hidayati, Ratna.2009. Metode dan Teknik Penggunaan Alat Kontrasepsi. Jakarta: Salemba Medika.

Hulland J, Chow, Y.H., \& Lam S. 1996. Use of Causal Models in Marketing Research: A Review. International Journal of Research in Marketing. pp. 181-197.

Kartajaya, Hermawan. 2006. Marketing in Venus. Jakarta : Gramedia PustakaUtama.

Kartajaya, H., Taufik, Mussry, J., dan Setiawan, I., 2012, Self Medication - Who Benefits and Who is at Loss, 3, Mark Plus Insight, Jakarta.

Kartajaya, Hermawan, 2007, Boosting LOYALTY MARKETING Performance : Menggunakan Teknik Penjualan, Customer Relationship Management, dan Servis untuk Mendongkrak Laba, Bandung, Mizan Pustaka.

Sekaran, Uma (2003), Research Methods For Business: A Skill Building Aproach, New York-USA: John Wiley and Sons, Inc

Setiawan, B. 2009. Pengaruh Padat Penebaran 1, 2 dan 3 Ekor/L terhadap Kelangsungan Hidup dan Pertumbuhan Benih Ikan Manvis (Pterophyllum scalare). [Skripsi]. Program Studi Teknologi dan Manajemen Akuakultur. Fakultas Perikanan dan Ilmu Kelautan. Institut Pertanian Bogor. Bogor.

Sharma, Rachna \& Vishal Sharma. (2011). Experiential marketing. A contemporary marketing mix. International Journal of Management and Strategyhttp://www.facultyjournal.com/ (IJMS) 2011, Vol. No.II, Issue 3, July-Dec2011 ISSN: 2231-0703 International Journal of Management and StrategyISSN:=22310703.

Smilansky, Shaz. 2009. Experiential Marketing: A Practical Guide to Interactive Brand Experiences. London and Philadelphia: Kogan Page.

Sumarwan, Ujang. (2003). Perilaku Konsumen, Teori dan Penerapannya Dalam Pemasaran. Ghalia Indonesia, Jakarta

Wijanto dan Istiningsih, 2007, Pengaruh Kualitas Sistem Informasi, Perceived Usefulness, Dan Kualitas Informasi Terhadap Kepuasan Pengguna Akhir Sofware Akuntansi, Simposium Nasional Akuntansi, Pontianak.

Wijayanti, Irine Diana Sari. 2008. Manajemen. Editor: Ari Setiawan.Yogyakarta: Mitra Cendikia.

Wilkie, William L. 1994. Customer Behavior (Third Edition). New York. Jhon Wiley \& Sons, Inc, S.

Zhang, Y., Liu, D., Chen, X., Li, J., Li, L., Bian, Z., et al., 2010. Article Secreted Monocytic miR-150 Enhances Targeted Endothelial Cell Migration. Mol Cell, 39: 133-144. 